\title{
Romanian letter-writing: a cultural-rhetorical perspective (I)
}

\author{
Ioan Milică ${ }^{1 *}$, Gabriela-Iuliana Morcov ${ }^{2}$ \\ ${ }^{1}$ Faculty of Letters, "Alexandru Ioan Cuza" University, Bd. Carol I 11, 700506 Iassi, Romania \\ ${ }^{2}$ Doctoral School of Philological Studies, "Alexandru Ioan Cuza” University, Bd. Carol I 11, 700506 Iași, Romania
}

\section{Article info}

History:

Received December 10, 2015

Accepted December 14, 2015

Published February 12, 2016

Key words:

rhetoric

letter

history of letter-writing

\begin{abstract}
The paper aims at revealing the cultural and rhetorical features of the Romanian letter-writing by outlining the key stages in the evolution of the letter in Europe and in the Romanian cultural space. In the subsequent ages, the profile of the rhetorical frame that enabled the development of letter-writing was governed by distinct guidelines, from the discursive canons of the Antiquity and the attempts to set out an epistolary theory in the postclassical age or the emergence of the medieval epistolary manuals and of the works of epistolary rhetoric from the Renaissance to the flourishing of private correspondence in the Baroque and the Enlightenment. The natural tendency to adapt the epistolary rhetoric to the idiomatic resources of the vernacular languages spoken in Europe favoured the outset and the advancement of a Romanian epistolary style whose cultural and rhetorical coordinates are sketched in the present article.
\end{abstract}

\author{
"The letter is a faithful messenger" \\ Bernhard Perger, Grammatica Nova, 1485
}

\section{Preliminary remarks}

A multimillennial history ties letter-writing to the life of human societies, and the epistolary cultures nourished by the avatars of this major communicative activity prove that along the way the letter was conferred a rich variety of uses, either of public or of private nature. As a means of ensuring long-distance communication between individuals and/or groups, the letter preserves historical data that highlight both the circumstances of the communicative process and the personality facets of the protagonists involved in the epistolary exchange.

The presence of the letter in various fields of human life reflects the old age of this efficient means of communication which was progressively adapted to face the challenges and the changes in technological progress, from the ancient Babylonian messages engraved on clay tablets (Roberts, 1843, p. 1) to the first medieval treatises on the art of letter-writing, ars dictaminis (Murphy, 2001, p. 203), and, later on, to the tradition of epistolary etiquette manuals (Bly, 2004) or to the electronic patterns of e-mails (Crystal, 2004, p. 94-128). More than a form of dialogue at a distance, as it was defined by some of the Greek and Roman rhetoricians, the letter is the expression of the human ability to store in writing flashing sequences from the kaleidoscope flux of reality, as filtered in the mind's laboratory of notions and images. From this point of view, one might even argue that all the relevant elements in the history of writing (Fischer, 2001), namely the writing tools, materials and devices, the types of writing and the canons of textual construction, also shed a light on the cultural destiny of the letter. Moreover, letters do not provide only the material evidence that certifies the advancements in the dynamics of writing, but they can also be interpreted as ideological artefacts that mirror the individual mentalities or the spirit of an age. Just as a painting offers the viewer clues and insights on both the outer, material world in which the artist lived and his/her inner universe of ideas and representations, letters guide the reader to re-enact the world-view of the epistler.

\footnotetext{
*Email address: ioanister@gmail.com.
} 
Ioan Milică, Gabriela-Iuliana Morcov

Given the wealth of forms and functions of letters, the analysis of the semiotic properties displayed by these texts must take into account a double reference, the one related to the conceptual frames that govern the compositional liberties and restrictions of letter-writing and the other related to the practices of the epistolary writing. The conceptual frames are created over time through the competition among various ideas and conceptions concerning the elaboration, the functions and the impact of letters in daily life. This theoretical quest is usually paralleled by a tradition of customs and habits in letter-writing. The (methodological) separation between the epistolary theory and the epistolographic tradition is useful in describing the epistolary cultures in which the practice of writing letters did not resonate with the theoretical constructs explicitly developed, but instead worked its way by virtue of tradition, up to the point in which certain customs became prestigious and started to act as models for further use. In the process of letter-writing, the separation between theory and practice could be used to signal the distinction between the explicit and the implicit patterns of the epistolary writing, on the one hand, and, the differences between the practices based on expert prescriptions and those guided by intuition and imitation, on the other hand.

The study of letters and epistolary theories enlightens the reticulate character of letter-writing ${ }^{1}$. By cohesion and coherence, the "snippets" of reality and mind called letters encode in the landscapes of their deictic $^{2}$ and symbolic ${ }^{3}$ fields modi vivendi that can constitute the object of a textual archæology such as the one proposed by Metzeltin \& Thir (2013).

\section{Stages in the evolution of letter-writing in Europe}

In Europe, the epistolary theory, ars dictaminis, was a medieval construct that marked the detachment from the oral spirit of the great Greek and Roman works of rhetoric (Camargo, 2006b, p. 271-275; Mack, 2011, p. 229; Murphy, 2001, p. 194). The gap deepened as the growing bureaucratic needs of the main medieval institutions (the royal and aristocratic chanceries, the church, the guilds, the army, the courts and the likes) appealed to more effective concepts, methods and tools and letter-writing proved to be in favour of this process of communicative expansion by specialization since it was adopted in the most important domains of medieval civilisation and culture: administration, art, diplomacy, economy, justice and religion. By longevity and impact, ars dictaminis became the most successful naturalisation of the classical rhetorical precepts to the peculiarities of medieval life (Camargo, 2006a, p. 60).

Without neglecting the persuasive potential of writing, the Greek $^{4}$ and Roman ${ }^{5}$ rhetoricians were mainly concerned with the compositional rules of orations (Perelman, 1991, p. 97). The art of public speaking was the communicative environment that favoured, by the $5^{\text {th }}$ century B.C., the rise of democracy in the Greek world, especially in Athens (Erskine, 2007, p. 272). The research on Greek rhetoric revealed that the ancient Greeks placed great trust in the virtues of oral communication so much so it modeled not only the mechanisms and the institutions of their social life, but also their views on the functions of speech, in general, at the time when writing and reading were in a very small measure defining attributes of the citizens in the polis (Thomas \& Webb, 1994, p. 6). Later, in Roman times, the oratorical routines

${ }^{1}$ Vlad (2008) offers a description of textual semantics by means of a definite set of distinctive features: reticularity, inferentiality, pluricodic character and synergy.

${ }^{2}$ According to Bühler, the human verbal communication assumes three deictic modes: the ostensive deixis, consisting in showing or indicating something, the anaphoric deixis, consisting in evoking something, which means expressing in words a fact that already happened, and deixis am phantasma, consisting of expressing something imaginary, i.e. rendering linguistically the products of one's imagination (Bühler, 2011, p. 94-95).

${ }^{3}$ If the deictic system outlines the circumstances in which the communication takes place (ego-hic-et-nunc), the symbolic field provides information about the context, more precisely about what is represented in the utterances (Bühler, 2011, p. 169f.).

4"Because of the scarcity and expense of writing materials in the Greek world, it is no surprise that this new technology was applied only to the most essential and the most eloquent examples of verbal communication." (Thomas \& Webb, 1994, p. 11).

${ }^{5}$ In Roman times, the art of words written in order to be spoken in public had an unprecedented development (Sciarrino, 2007, p. 55). 
grown under the influence of Greek rhetoric became more and more ritualized, as far as the composition and delivery of various types of orations were concerned (Dominik \& Hall, 2007, passim; Habinek, 2005, passim). To put it differently, the importance attributed to oratory was convergent with the rhythms of public life in the Antiquity.

The thorough investigation of the rhetorical virtues of orality sprang from the conscience that the right to speak about the capital issues in the life of the city implied to set in motion a communicative process with three cardinal points (Meyer, 2010, p. 37-38): a) the issue(s) of civic interest (the problematisation of reality by means of language), b) a speaker apt to master the words, i.e. a person aware of the power of language over the hearts and minds of the others (the orator), and c) a public ready to react to what is being said (the auditory).

The awareness that the two channels of verbal communication, speaking and writing, have distinct stylistic profiles was clearly stated since the times of Aristotle ${ }^{6}$ and taken into account in all major ancient works devoted to the art of eloquence. However, the prevalence of orality over scripturality was steadily emphasized, as proven by the comments of Quintilian (1920, I.8) on the techniques of reading and understanding literary and oratorical texts.

The interest granted to the oratorical craft favoured the rise and flourishing of extensive and fertile Greek and Roman epistolary cultures that bring forth the nobility of letters as means of public and private communication (Roberts, 1843, passim). Without contributing to the creation of a body of epistolary theories included in the rhetorical treatises of the age, the great spirits of the Antiquity left as a legacy to posterity the treasure of a consistent corpus of epistles that, in the coming ages, would act as the foundation on which new theoretical perspectives on the cultural destiny of letter-writing were to be built. Consequently, the statement that in the Antiquity letter-writing must have been coherently developed according to a rather implicit view powered by various discursive traditions than to explicit theoretical frameworks is consistent with the idea that the earliest attempts to set out a theory on letter-writing most probably dates from the postclassical age ${ }^{7}$ (Poster, 2007, p. 21). In the light of some of the texts preserved from the first five centuries of the Christian age, it could be inferred that the epistolary theory of the time had reached a remarkable rhetorical refinement if one is to take into consideration the complex taxonomy of letters provided by some works ${ }^{8}$.

After the fall of the Western Roman Empire, the art of letter-writing gained popularity among the

\footnotetext{
${ }^{6}$ In his Rhetoric (III.12), Aristotle appeals to the principle of adequacy and harmony of proportions in order to indicate the stylistic difference between writing and speaking: "The style of written prose is not that of spoken oratory (...). Compared with those of others, the speeches of professional writers sound thin in actual contests. Those of the orators, on the other hand, are good to hear spoken, but look amateurish enough when they pass into the hands of a reader".

${ }^{7}$ A reader edited by Abraham J. Malherbe (Ancient Epistolary Theory, Scholars Press, Atlanta, Georgia, 1981) includes authors from up to the $4^{\text {th }}$ century A.D.: Demetrius, Cicero, Seneca, Pseudo-Demetrius, Philostratus of Lemnos, Gregory of Nazianzus, Julius Victor and Pseudo Libanius.

${ }^{8}$ In a study devoted to the epistolary theories proposed at the end of the classical age, Poster (2007, p. 21-51) notes, by quoting Malherbe, that Typoi Epistolikoi, a work attributed to Pseudo-Demetrius, outlines a taxonomy including 21 types of letters, whereas another letter-writing manual, Epistolimaioi Kharactêres, attributed to Pseudo-Libanius, delineates a more comprehensive classification, including 41 types of letters. Written in a concise and simple style, the already mentioned works seemed to be addressed to the educated members of the aristocracy and to the students attending schools in which rhetoric was taught. As an illustration, we render the taxonomy advanced in Epistolimaioi Kharactêres (apud Iovine, 2010, and also mentioned in Poster, 2007, p. 28-30): 1) parainetikē (parainetic); 2) memptikē (blaming); 3) paraklētikē (requesting); 4) systatikē (commendatory); 5) eirōnikē (ironic); 6) eucharistikē (thankful); 7) philikē (friendly); 8) euktikē (praying); 9) apeilētikē (threatening); 10) aparnētikē (denying); 11) paraggelmatikē (commanding); 12) metamelētikē (repenting); 13) oneidistikē (reproachful); 14) sympathētikē (sympathetic); 15) therapeutikē (conciliatory); 16) sygcharētikē (congratulatory); 17) paralogistikē (contemptuous); 18) antegklēmatikē (counteracusing); 19) antepistaltikē (replying); 20) paroxyntikē (provoking); 21) paramuthētikē (consoling); 22) hybristikē (insulting); 23) apaggeltikē (reporting); 24) schetliastikē (angry); 25) presbeutikē (diplomatic); 26) epainetikē (praising); 27) didaskalikē (didactic); 28) elegktikē (reproving); 29) diablētikē (maligning); 30) epitimētikē (censorious); 31) erōtēmatikē (inquiring); 32) paratharryntikē (encouraging); 33) anathetikē (consulting); 34) apophantikē (declaratory); 35) skōptikē (mocking); 36) metriastikē (submissive); 37) ainigmatikē (enigmatic); 38) hypomnēstikē (suggestive); 39) lypētikē (grieving); 40) erōtikē (erotic); 41) miktē (mixt).
} 
members of the Byzantine Empire intellectual elite. More precisely, since the $4^{\text {th }}$ century A.D. there was an undeniable intertwining of the ancient Greek rhetorical legacy and the Christian rhetorical and epistolary tradition. With reference to St. Paul's epistles that St. Augustine capitalized on as models of eloquence in his well-known De doctrina christiana (396-426), the Cappadocian Fathers contributed to the creation of an illustrious epistolary vein that was to be treasured and valued in the centuries to come (Silvas, 2007). It is no wonder that in the article on epistolography included in The Oxford Dictionary of Byzantium it is stated that, after the flourishing age of letter-writing, in the $4^{\text {th }}$ century A.D., the Byzantine epistolary practice faced a period of stagnation followed by regress in order to reach new heights in letter-writing accompanied by verse commentaries (Jeffreys \& Kazhdan, 2000, p. 718-720).

In the Antiquity, the official correspondence was destined to public reading (Radner, 2014 ${ }^{9}$ ). As letters were read in the presence of the addressee (the ruler) and of an audience who was keen to understand and appreciate the significance of the reading ritual, the act of letter-writing enabled, through its stylistic feature of orality, a discursive ceremonial endowed with multiple social and cultural roles. In the Byzantine age, the letter-bearers, grammatophoroi, were regarded as living letters, since they performed the role to deliver the factual information, whereas the letters themselves adorned the oral messages carried by the couriers. In addition, the epistolary typology was determined by the purpose and the content of the letters.

According to their purpose, letters were official, private and literary. The official letters sent by the imperial court and by the high clergy were recorded in the public archives. The private letters reflected the nature of the relationship between the sender and the recipient, as well as their opinions on various aspects of life, whereas the literary letters destined to a large audience had an æsthetic function, as they referred to imaginary characters and situations. According to their content, letters were usually divided into diplomatic, theological and scholarly (Jeffreys \& Kazhdan, 2000, p. 719). As part of the Byzantine official discursive ceremonial, the letter consisted of an initial protocol, a context and a final protocol. As ritualized formulas denoting a phatic rhetoric (Perelman, 1991, p. 107f.), the initial and final protocols generally mirrored the impact of the Christian doctrine on the epistolary practice, as evidenced by the use of the topos of modesty (tapeinotes, Kazhdan \& Ševčenko, 2000, II, p. 1387). In other words, in the high culture of the age, letter-writing bore the marks of the identity and prestige of the protagonists involved in the exchange of letters sent either for administrative, æsthetic, legal, political or religious purposes or for private reasons.

In the emergent feudal society, the more complex social stratification began to be mirrored in writing by the advent of formula, which were documents with fixed structure. The formula applied to the circumstances claiming their use and ensured, at least in Western Europe, the survival of educated writing in the period between the $7^{\text {th }}$ and the $9^{\text {th }}$ centuries A.D. Around the year 1000, the level of education in Europe succumbed to a highest low in comparison with the first six centuries of the Christian age (Murphy, 2001, p. 199-202). It was in this period of stylistic simplicity and austerity of the epistolary writing that in the Benedictine abbey of Monte Cassino the first medieval epistolary manuals of Alberic of Monte Cassino (Figure 1) and his apprentice John of Gaeta, chancellor of the Papal administration between 1089 and 1118, and Holy Father (Pope Gelasius II, 1118-1119), appeared. The Papal Chancery played a major influence upon the development, the formalisation, and the popularization of the rhetorical conventions of the epistolary writing (Perelman, 1991, p. 100).

In essence, Alberic's contribution to the naissance of epistolary rhetoric materialized in the standard-

\footnotetext{
${ }^{9}$ In the introduction, the editor of this volume published by an international group of historians reveals that the research covered the timeline between the $15^{\text {th }}$ century B.C. and the $6^{\text {th }}$ century A.D. and it was centered on key-topics such as: " 1 . What are the roles of envoys and letters in long-distance state communications? 2. What is the role of scribes and secretaries? 3. What languages are used for the state correspondence? 4. Is there a privileged state communication system? How is it organized? 5. How is information safeguarded while in transit? 6. Are there patterns and routines of state communication? 7. Are there obligatory rules of communication? 8. When and how are letters publicized? 9. Are letters archived for future reference?" (Radner, 2014, p. 3-4).
} 
III.

\section{Diffinitio opistole.}

Est igitur epistola congrua sermonum ordinatio ad exprimendam intentionem delegantis instituta. uel aliter epistola est oratio ex constitutis sibi partibus congrue ac distincte conposita delegantis affectum plene significans.

\section{IV.}

\section{De partibus opistole.}

Cuius uidelicet quinque sunt partes: salutatio, beniuolentie captatio, narratio, petitio, atque conclusio.

Figure 1: A passage from the treatise of Alberic of Monte Cassino, Rationes dictandi, excerpted from Rockinger (1863, p. 10).

ization of the parts of the letter, in the tone of the salutations and introductory sections according to statuses of the epistlers, in certain recommended principles of expressive adornment of epistles (colores), in the enactment of letter models and official forms and, equally important, in the encouragement of rhythmical prose for letter-writing, so that the letter would be highly persuasive when read aloud (Murphy, 2001, p. 210).

The process of organizing letter-writing in agreement with the principles of Ciceronian rhetoric (Table 1) was further elaborated by Adalbertus of Samaria and Hugh of Bologna, so that, in the $12^{\text {th }}$ century, the Bolognese ars dictaminis began to spread in the great monastic centres throughout Europe, first in France (Figure 2) and later in Southern Germany, to the extent that this rhetorical framework stimulated hundreds of treatises and thousands of manuscripts devoted to letter-writing (Camargo, 2006a, p. 60).

\begin{tabular}{ll} 
Cicero: Parts of an Oration & The School of Bologna: Parts of a Letter \\
\hline Exordium (Exordium) & Salutatio (The Salutation) \\
- & Captatio benevolentia (The Securing of Goodwill) \\
Divisio (Division) & - \\
Narratio (Narration) & Narratio (The Narration) \\
Confirmatio (Confirmation) & Petitio (The Petition) \\
Refutatio (Refutation) & - \\
Peroratio (Peroration) & Conclusio (The Conclusion)
\end{tabular}

Table 1: Parts of an oration and parts of a letter (according to Murphy, 2001, p. 225).

At the same time, it is worth revealing that "the introduction of theoretical rigor into long-standing pedagogical practices that resulted in the ars dictaminis was a response to the need for more efficient training of functionaries. In northern Italy, the struggles between the papacy and the emperor, the expansion of commerce, and the development of communal forms of government all resulted in an unprecedented demand for trained clerks to serve in roles ranging from municipal notaries to papal secretaries and imperial chancellors. (...) As medieval social and economic powers structures grew more complex and more text-dependent, medieval teachers responded with a flexible and efficient means of preparing the literate class that kept the necessary documents flowing" (Camargo, 2006a, p. 61).

The fact that in the Middle Ages the style of letter-writing called cursus was not confused with the composition rules of other chancery documents could be proved, among other things, by the distinction between ars dictaminis and ars notaria. Without being completely separated from one another, the two curricular paths in the monastic education of the $13^{\text {th }}$ century were reflected by distinct manuals and evolved rather autonomously (Murphy, 2001, p. 264f.; Witt, 1982, p. 25).

Written in convergence with the precepts advocated by the medieval treatises or prepared as polemic reactions to the feudal epistolary canon, "Renaissance letter-writing manuals share many features. They generally define the letter, divide letters into types, provide recipes for and examples of each type, and give 
I.

De dictamine.

Quia nobis est propositum tractare de arte dictaminum, primum videndum est quid sit dictamen.

Dictamen sic diffinitur. dictamen est literalis edicio, venustate sermonum egregia, sententiarum coloribus adornata. Dictaminis autem plures sunt species. dictamen aliud est metricum, aliud prosaicum. de metrico nihil ad presens. Prosaici vero plures sunt species: oracio, rethorica, epistola. et etiam pretermissis aliis de epistola agamus.

II.

\section{Do opistola.}

Epistola sic diffinitur. epistola est oracio congrua suis e partibus conuenienter conposita affectum mentis plene significans. oracio congrua dixi ad exclusionem earum que non sunt oraciones. suis e partibus dixi, quia quinque sunt partes dictaminis: salutacio, exordium, narracio, peticio, et conclusio. conuenienter con posita dixi, quia quod primum est in dictamine non debet fieri medium vel vltimum, vel e conuerso. affectum mentis plene significans, quia ille qui mittit illi cui mittitur animum suum debet declarare.

Figure 2: A passage from the treatise Incipit Summa Dictaminis of the School of Orléans, excerpted from Rockinger (1863, p. 103).

advice on formulas of address" (Mack, 2011, p. 228).

For Renaissance authors of letter-writing manuals, the rediscovery of the principles of ancient rhetoric had, in many respects, a remarkable impact.

First, changes were made to the discursive canon of letters. Whereas the medieval scholars were mainly concerned with the official epistolary style, the Renaissance erudites ${ }^{10}$ were increasingly interested in the rhetorical features of private letters. The deconstruction of the medieval standard in letter-writing was gradually achieved. For instance, the Italian humanist Giovanni Mario Filelfo composed Novum epistolarium seu ars scribendi epistulas (1477) and established a taxonomy of eighty different types of letters, classified according to the ancient threefold division of style: simple style, temperate style and grand style. This compositional hierarchy of the epistolary writing was thereby actualized and allowed a more appropriate charting of the stylistic distinctions between very familiar letters, mostly corresponding to the simple style, familiar letters, usually elaborated in a temperate style, and solemn letters, conceived in grand style (Mack, 2011, p. 236).

A more radical reform was put forth by Erasmus of Rotterdam. In a vein similar to other authors, the Dutch erudite replaced the rhetorical division of the medieval letter with a new template shaped under the influence of the classical rhetorical genre theory (Mack, 2011, p. 242-243). According to his taxonomy, deliberation was proper to letters of persuasion and dissuasion, encouragement and discouragement, petition, advice, and love letters, namely those epistles discussing the honorable, the useful and the possible. The judicial genre included letters of accusation, refutal, vituperation, and justification, in other words, all epistles referring to accusation and defense. Letters of praise were subsumed under the demonstrative (epideictic) genre. Furthermore, Erasmus was one of the first scholars who brought a modern perspective on the study of epistolarity, as he insisted on the interactive (intersubjective) nature of verbal communication by means of letter-writing. In the stylistic economy of letters, the key compositional factors are tied to the receiver's identity, the writer's relationship to the addressee and the thematic content of the letter (Mack, 2011, p. 246). Thus, a pragmatic view of letter-writing was foreshadowed with reference to the

\footnotetext{
${ }^{10}$ In his volume dedicated to the Renaissance rhetoric, Peter Mack focuses upon such writers as Niccolò Perotti (14301480), Francesco Negro (n. 1452), Erasmus of Rotterdam (?1469-1536), Juan Luis Vives (1492-1540) or Justus Lipsius (1547-1606).
} 
axis sender - epistolary message - recipient.

Another important Renaissance scholar, Justus Lipsius, conceived a threefold typology of letters (Mack, 2011, p. 254), seemingly based on the functional opposition between the public and the private: serious letters, specific to public interaction, learned letters, proper to both public and private communication particularly within such fields of high culture as philology, philosophy and theology, and familiar letters, typical for private interaction. The same author established a definite set of stylistic traits for any epistolary text $^{11}$.

Second, the Renaissance scholars expressed the need to reevaluate the rhetorical identity of letterwriting in the light of the newly emerging realities of the age. The ancient and medieval authors of letterwriting treatises insisted that the official letter was intended to be read aloud in front of an audience, a fact proven by the constant use of rhythmic prose and, implicitly, of its persuasive and expressive effects. In the view of the Renaissance erudites, the traditional epistolary ceremonial was rather obsolete, so it required to be replaced by more flexible and innovative rhetorical frames, fit to mirror the changes that occurred within the public and private correspondence from the beginning of the $15^{\text {th }}$ century. In other words, the phatic and conative ritualized protocols of the official epistles could no longer be imposed to familiar letters, which were felt to have a "conversational" and non-public nature. In Epistolica Institutio (1591), for instance, Justus Lipsius suggested that the form and content of familiar letters did not have to flow in a strict order, but rather to reflect, in terms of compositional flexibility, the writer's interests, just like in conversation (Mack, 2011, p. 255).

Finally, letter-writing transformed during Renaissance, as the stage of quasi mechanical imitation was left behind for a newly established framework of highly creative imitation. For example, according to Erasmus, written communication by means of correspondence could achieve a certain prestige insofar as the imitation of illustrious model letters was interwoven with training, steady practice and exercise of judgment (Mack, 2011, p. 242). Therefore, not everything that was allowed was necessarily useful. Moreover, we ought to show that, starting with the $16^{\text {th }}$ century, letter-writing gradually adopted the attire of vernacular languages and this adaptation to the idiomatic resources of the various languages spoken in Europe prompted, in the $17^{\text {th }}$ century, an unprecedented flourishing of the epistolary communication (Camargo, 2006b, p. 272).

Throughout the $17^{\text {th }}$ and $18^{\text {th }}$ centuries, the letter, the familiar letter in particular, gained preeminence as a literary form. In Western Europe, the awareness that the art of letter-writing resembled the art of conversation prompted the renewal of the epistolary style which, at the time, took over some of the stylistic features of the conversational etiquette enthusiastically rehearsed on the stages of the aristocratic salons: elegance, vividness, brightness and wit. Almost naturally, the epistolary rhetoric came to be known as the art of simulating sincerity, artlessness and spontaneity. It was the age when the collections of imaginary letters crafted to fulfil the æsthetic function of entertainment became highly popular; it was the age when the fashionable literary form of the epistolary novel achieved new heights of notoriety (Camargo, 2006b, p. 273). In other words, the functional nature of the letter changed significantly since its phatic and conative protocols gave way to an emerging epistolary rhetoric animated by æsthetically oriented means of expressiveness (Gurkin Altman, 1982, passim).

From the dawn of the Industrial Revolution, as new technologies like printing, paper production machinery, typewriting machines and telecommunications (the telegraph, the telephone and especially the Internet), partly in the $19^{\text {th }}$ century, partly in the $20^{\text {th }}$ century, gained increasing impact in the routines of daily life and the letter's cultural and rhetoric prestige diminished inasmuch as the elevated and timehonored art of letter-writing was dissolved into a minor genre of utilitarian writing, practised almost automatically on a daily basis.

\footnotetext{
${ }^{11}$ We shall discuss the matter in the second part of our article.
} 


\section{Stages in the evolution of letter-writing across the Romanian cultural territory}

In the regions inhabited by the Romanians, the evolution of letter-writing in the vernacular language has been closely related to the level of social development and, thereby, to the history of Romanian as the communicative tool for the literate people ${ }^{12}$ and as language of culture. The letter of the merchant Neacșu of Cîmpulung to Johannes Benkner, the mayor of Brașov, dating from [the $29^{\text {th }}-30^{\text {th }}$ of June] 1521, is the first preserved document written in Romanian and, at the same time, "the oldest testimony of a Romanian epistolary style" (Chițimia \& Toma, 1984, p. 32-33). Written in the Cyrillic alphabet and crafted after a Slavonic template, the letter illustrates the epistolary customs of the time, as one can notice by analyzing the discursive sequences corresponding to the initial and the final protocol. "The fluency of sentence, the clarity of phrasing, the accuracy of reasoning, the brevity in transmitting secret information, the prevalent lexis of Romanic origin, the use of phrases from the spoken language, the limited number of archaic forms in morphology and syntax" (Chițimia \& Toma, 1984, p. 29) are defining aspects whereby Neacșu's letter supports the claim that the tradition of written Romanian predates the beginning of the sixteenth century (Densusianu, 1938, Gheție, 1982, Gheție \& Mareș, 1974, Ivănescu, 2000, Munteanu \& T, Târa, 1983, Philippide, 1888, Puşcariu, 1987, Rosetti, 2002, etc.) At the same time, the letter proves that, in most parts of Europe, ars dictaminis was rapidly adapting to the idiomatic resources of various vernacular languages.

We will pass by the intricacies of many historic details, only to state that the study of the collections of old acts and documents ${ }^{13}$ used across the territory inhabited by the Romanians reflects the presence of two major epistolary templates: the western, Roman type, materialized in letters written in the medieval Latin and in some other languages spoken by the Romanians' catholic neighbours (German, Hungarian etc.), and the eastern, Byzantine type, witnessed in texts drawn up in accordance with the Slavonic and Greek traditions (Camariano-Cioran, 1971, Iorga, 1972, Panaitescu, 1965). Before the emergence of the earliest letters written in Romanian (the $16^{\text {th }}$ century), the chanceries were dominated by the epistolary templates mainly following the Roman (cf. series DRH C Transilvania) or the Slavonic tradition (cf. series DRH B Țara Românească and DRH A Moldova), as the use of one semiotic template or another was governed by different "cultual" and cultural necessities ${ }^{14}$.

Between the $16^{\text {th }}$ and the $17^{\text {th }}$ centuries the structure and the stylistic traits of the epistolary text as well as the taxonomy of letters written in Romanian ${ }^{15}$ certify the existence of an epistolary style, initially formed under the influence of foreign models (see Bădescu, 2003).

From the $18^{\text {th }}$ century onwards, the practice of letter-writing was paralleled by a growing body of

\footnotetext{
12 "Our legacy of old secular writings is-if not extremely abundant in the first century of the attested Romanian writings $\left(16^{\text {th }}\right.$ century $\left.\mathrm{AD}\right)$ - miscellaneous enough, and it has grown richer in the course of time: it includes letters (official or particular), deeds (of sale, purchase, donation or exchange), wills, orders, safe conducts, testimonies, memoranda (about particular expenses, about tribute or about an estate division), inventories (of wealth or dowry, of aid or toll), confirmation documents, pieces of evidence, receipts, notes, calculations (of income and outlays), diplomatic documents, registers, bank drafts, acts (concerning marriage, property delimitation), itineraries etc." (Chițimia \& Toma, 1984, p. 29).

${ }^{13}$ In our research we will refer mainly to Documenta Romania Historica (DRH), a series of documents compiled under the ægis of the Romanian Academy, without losing sight of other collections created by groups of linguists like Chivu et al. (1979), Chițimia \& Toma (1984), and others.

${ }^{14}$ For details regarding the impact of the "cultual" - cultural tension in the translation of Old Romanian texts see, for instance, Gafton (2012, p. 127-153).

${ }^{15}$ We shall insist upon this issue in the second part of our article.
} 
imported epistolary theory preserved in manuscripts ${ }^{16}$ and printings ${ }^{17}$. During the $19^{\text {th }}$ century ${ }^{18}$, most of the Romanian letter-writing manuals followed the same guiding points provided by foreign, mostly French, models. In general, such manuals are loose translations of didactic handbooks, as one can learn from the opening pages of the Epistolariu culesu shi intocmitu asfelu by C. Donescu, which includes "the instructions given by Mr. Fhilipon de la Medelaine, concerning the epistolary style in general, namely its required qualities, but also every particular type of letter, all being adapted to the nature of our own language" (Donescu, 1840, p. IV).

By analysing the letter-writing manuals published by V. Urzescu and C. Donescu, one can see how the western models were reshaped and adapted to fit the Romanian socio-cultural background. Similar in terms of structure and content, both manuals stress the idea that the amateur, occasional writer of letters should master the principles of the epistolary style and the ritual formulas adequate to different circumstances in either official or private correspondence. The collections of model letters are preceded by preparatory pages in which the authors systematically resume prescriptions grounded in the epistolary theory of the time. In connection with the rhetorical precepts of Renaissance erudites, the epistolary style is related to the threefold distinction simple style - temperate style - grand style, and the attempts to provide definitions for various types of letters are rooted in the rules of conversational etiquette, so that certain stylistic qualities of letter-writing, such as "the intelligibility, the politeness and the purity of language" (Urzescu, 1840, p. 4) should reflect, for each type of epistolary exchange, the participants' concern to devise the appropriate discourse in order to adequately capture the relationship between them.

The opening chapters of the manuals are completed with suggestions regarding the form of the letter, by mentioning a set of particular rules concerning "a letter's material ceremonial: that is the inside condition, the signature, the means of sealing and the manner of closing the letter into an envelope" (Urzescu, 1840, p. 10). Whereas the written communication between friends or family members implies a certain neglect of conventions, formal letters to a high-ranking addressee must follow a well-defined protocol, individualized by style, particularly in terms of opening and closing formulas, and also of the linguistic quality of the letter. Thus, the address must reflect the recipient's position or rank (Sire [Sire], Prea Înălțate Doamne [Your Highness], Domniia ta [Your Worship], Domnule [Mister], Doamnă [Mrs.], etc.) and the ending formula ought to be similarly created in a formal or reverential tone: "Sint cu cinstirea cea mai

\footnotetext{
${ }^{16}$ Ileana Oancea (1988, p. 81-82) extracted from Catalogul manuscriselor româneşti [The Catalogue of Romanian Manuscripts], published by G. Ștrempel between 1978 and 1992, the list of manuscripts including elements of epistolary theory: Epistolar în limba slavonă și română, the $18^{\text {th }}$ century (MS 2456); Manual de corespondență, 1787 (MS 2746); Fragment de manual epistolar, the $19^{\text {th }}$ century (MS 1143); Modele de scrisori, acte și cuvintări ocazionale, the $19^{\text {th }}$ century (MS 1686); Manual epistolar, the $19^{\text {th }}$ century (MS 1800), Epistolografie, 1841 (MS 4185); Formulări epistolare, the $19^{\text {th }}$ century (MS 4364); Epistolar, 1845 (MS 5808).

${ }^{17}$ One of the earliest letter-writing manuals printed at the end of the $18^{\text {th }}$ century within the Romanian cultural territory is the work of Dimitrie Eustatievici Brașoveanul, Scurt izvod pentru lucruri de obște și de chilin în scrisori de multe chipuri. De pre limba slovenească pre limba rumînească scos și întocmit, spre folosul pruncilor neuniți, published at Sibiu, in the Typography of Petru Bart, in 1792. The typographer would reprint the handbook in 1803, under a different title- $\hat{I n v a ̆ t ̦ a ̆ t u r a ̆ ~ f o a r t e ~ f o l o s i t o a r e ~}$ pentru facerea răvașelor sau scrisoarelor, inștanțiilor, contracturilor, dieților sau testamenturilor și darea titulelor fieștecăruia stat și altele - without mentioning the translator's name (Fugariu, 1970, I, p. 138-140; Soare, 2013, p. 66-68).

${ }^{18}$ The year 1840 stands out through the publication of two letter-writing manuals: V. Urzescu, Epistolar sau modele de scrisori pentru tot felul de trebuințe, cules din cei mai vestiți autori noi și vechi, franțezi și alți, cu formulele politeții moderne..., Tome I, București, 1840 and C. Donescu, Epistolariu culesu shi intocmitu asfelu, București, 1840. In the following years, other handbooks would be printed: Constantin Diaconovici Loga, Epistolariul românesc pentru facerea a tot feliul de scrisori ce sînt in viața societății omenești la multe întîmplări de lipsă (acum întîia oară lucrat de CDL), Pesta, 1841; Sava Popovici, Epistolar sau carte de învățătură pentru deprinderea în corispondințe și scrisori, atît private cît și politice, care vin mai des în viața omenească inainte, Sibiu, 1847; A. Pretorian, Cursu Practicu de stilu epistolaru, dupe V. Doublet, București, 1857; Sava Popovici, Epistolar sau carte de învățătură pentru deprinderea în corispondințe și scrisori, atît private cît și politice, second edition, Sibiu, 1863 ; I. Suchianu, Noțiuni de stil și composițiuni cu bucăți din autorii români vechi și moderni. Stil epistolar pentru uzul clasei a IV-a secundare, București, 1898 ( $1^{\text {st }}$ edition, 1890). The list of $19^{\text {th }}$ century writings may be completed with manuals and treatises of rhetoric that include chapters devoted to the art of letter-writing, such as D. Gusti’s Ritorică română pentru tinerime, Iași, 1852; the $2^{\text {nd }}$ edition, Ritorică română, Iași, 1875.
} 
deosebită...” [Please accept the assurance of my highest consideration...] (Urzescu, 1840, p. 11), „Priimește inchinăciunea simtimentelor mele celor mai alese ceți-am mărturisit..." [Please accept the expression of my most distinguished sentiments] (Donescu, 1840, p. 39), etc.

The explicit purpose of the already mentioned letter-writing manuals is that of helping the educated reader to acquire the elementary principles of letter composition, not so much by means of an imposed set of rules, as through his or her acquaintance with prestigious models, which are worth imitating while conducting the personal correspondence. Hence, the largest part of each manual gets an illustrative function, by bringing together pieces of the greatest letter writers' correspondence, organized by subject-matter in well-defined categories. The main types of letters, shared by both compilations are: New Year letters, congratulatory letters, letters of sympathy, letters of request, thank-you letters, letters of recommendation, letters of friendship, familiar or amusing letters, personal updates letters. Furthermore, Donescu's Epistolariu... includes examples of serious and moral letters, rebuttal letters, make-amends letters, but it excludes "love letters that would bring shame upon any letter-writing manual” (Donescu, 1840, p. IV). Urzescu's manual stands out through some different species: invitation letters and notes, get-well letters, without closing the door on love letters or even on proposal of marriage letters and these types will last until the second half of the $20^{\text {th }}$ century, as reference points for the written guides of good manners. The inductive nature of the two handbooks is revealed by the appeal to a number of simple model letters, easy to be adapted to the interlocutors' age and social status and apt to act as guidelines for very common communicative circumstances in letter writing: letter from a son to his father, letter to a protector, to a friend etc.

The two manuals also resemble in their expository techniques. Each category of letters is provided with a brief description that insists upon its distinctive features and the didactic approach continues with the insertion of some selected letters and, if possible, of their corresponding replies, the examples being excerpted from the correspondence of some of the greatest letter writers: Madame de Sévigné, Racine, Voltaire, Rousseau and others.

Designed "for the general needs and use" (Urzescu, 1840, p. XV), the two handbooks meet the most diverse communicative needs of the epistolary interaction and the opening pages announce the publication of some later volumes intended to prove the complexity of business correspondence. Moreover, $\mathrm{V}$. Urzescu mentions his plan for a third part of the manual to complete his epistolary assembly with letters on moral issues, philosophy, politics or literature. As a general note, such manuals mirror the dynamics of those stylistic and rhetoric qualities that define the Romanian epistolary genre in its evolution, especially in the second half of the $19^{\text {th }}$ century and the first half of the $20^{\text {th }}$ century.

If throughout the old period of Romanian culture the letter was most frequently used as diplomatic, administrative or commercial device in official circumstances, the $18^{\text {th }}$ and $19^{\text {th }}$ centuries witness its rise towards the fine society where it becomes a reflection of excellent education and a symbol of a refined communicative etiquette. In the previous centuries, the letter writer would elaborate his epistles written in Romanian obeying the standard formulary of the Slavonic template, imposed by the chanceries' epistolary practice, either individually or, most frequently, by means of a scribe, and without being guided by explicitly prescriptive theoretical writings. The technological progress and the renewal of the socio-cultural life enabled the letter to face an increasing diversity of social and cultural contexts and, in this climate, the need of guidelines naturally led to the compilation of the first letter-writing manuals published in Romanian, elaborated by means of translation, adaptation and imitation of the foreign models. Through creative mimesis, translators and authors of letter-writing manuals assume the identity of a master, addressing to all those who wish to grow accustomed with the art of letter-writing, but most of all, to the youth and young ladies, namely to the young people that learn ars dictaminis in institutions such as public schools and boarding schools. In this flourishing age of Romanian letter-writing, the attempts to justify the usefulness of epistolary handbooks changed easily into acclaims of the letter: "A letter that is written with good sense, beautifully embellished and arranged in an organized way (...) proves one's genuine virtue, soul, good education and even one's character, achieving praise and honor from all those who have read it and, besides, it often lays the foundation of a bright future" (Urzescu, 1840, p. XII). 


\section{Bibliography}

Aristotel (2004). Retorica, bilingual edition, translation, introduction and index by Maria-Cristina Andrieș, notes and comments by Ștefan-Sebastian Matei, Editura Iri, București.

Bădescu, L. (2003)....și au scris carte... Eseu asupra epistolei medievale în literatura română, Editura Ars Docendi, București. Bly, R. W. (2004). Webster's New World Letter Writing Handbook, Wiley Publishing Inc., Indianapolis, IN.

Bühler, K. (2011). Theory of Language. The Representational Function of Language, translated by Donald Fraser Goodwin in collaboration with Achim Eschbach, John Benjamins Publishing Company, Amsterdam - Philadelphia, CrossRef.

Camargo, M. (2006a). Ars dictaminis, in Sloane, T.O. (ed.), Encyclopedia of Rhetoric, Oxford University Press, p. 60-62, CrossRef.

Camargo, M. (2006b). Epistolary Rhetoric, in Sloane, T.O. (ed.), Encyclopedia of Rhetoric, Oxford University Press, p. 271-275, CrossRef.

Camariano-Cioran, A. (1971). Academiile domnești din București și Iaşi, Editura Academiei R.S.R., București.

Chițimia, I. C. \& Toma, S. (coord.) (1984). Crestomație de literatură română veche, vol. I, Editura Dacia, Cluj-Napoca.

Chivu, Gh., Georgescu, M., Ioniță, M., Mareș, Al. \& Roman Moraru, A. (eds) (1979). Documente și însemnări românești din secolul al XVI-lea, Editura Academiei R.S.R., București.

Crystal, D. (2004). Language and the Internet, Cambridge University Press, CrossRef.

Densusianu, O. (1938). Histoire de la langue roumaine, tome II, Le seizième siècle, Librairie Ernest Leroux, Paris.

Dominik, W. \& Hall, J. (eds) (2007). A Companion to Roman Rhetoric, Blackwell Publishing.

Donescu, C. (1840). Epistolariu culesu shi întocmitu asfelu, Tipografia lui Eliad, București.

Erskine, A. (2007). Rhetoric and Persuasion in the Hellenistic World: Speaking up for the Polis, in Worthington, I. (ed.), A Companion to Greek Rhetoric, Blackwell Publishing.

Fischer, S. R. (2001). A History of Writing, Reaktion Books, London.

Fugariu, F. (ed.) (1970). Scoala ardeleană, 3 volumes, introduction and notes by Romul Munteanu, Editura Albatros, București.

Gafton, Al. (2012). Reflectarea tensiunii cultural/cultual in procesul de declarare a surselor textului biblic. Cazul vechilor traduceri românești, in "Analele Universității «Alexandru Ioan Cuza» din Iași”, section IIIe. Lingvistică, tome LVIII, p. $127-153$.

Gheție, I. (1982). Introducere în studiul limbii române literare, Editura Științifică și Enciclopedică, București.

Gheție, I. \& Mareș, Al. (1974). Introducere în filologia românească, Editura Enciclopedică Română, București.

Gurkin Altman, J. (1982). Epistolarity. Approaches to a Form, Ohio State University, Columbus, OH.

Habinek, Th. (2005). Ancient Rhetoric and Oratory, Blackwell Publishing, CrossRef.

Iorga, N. (1972). Bizanț după Bizanț, Editura Enciclopedică Română, București.

Iovine, A. (2010). Teoria e prassi dell'epistolografia greca tardoantica, Università degli studi di Napoli “Federico II”, PhD manuscript, [online].

Ivănescu, G. (2000). Istoria limbii române, edited by Mihaela Paraschiv, Editura Junimea, Iași.

Jeffreys, E.M. \& Kazhdan, A.P. (1991). Epistolography, in Kazhdan, A.P. (ed.), The Oxford Dictionary of Byzantium, vol. I, Oxford University Press, Oxford - New York, p. 718-720, CrossRef.

Kazhdan, A.P. \& Ševčenko, I. (1991). Modesty, Topos of, in Kazhdan, A.P. (ed.), The Oxford Dictionary of Byzantium, vol. II, Oxford University Press, Oxford - New York, p. 1387, CrossRef.

Mack, P. (2011). Letter-Writing Manuals, in A History of Renaissance Rhetoric 1380-1620, Oxford University Press.

Metzeltin, M. \& Thir, M. (2013). Antropologia textului, Romanian translation by Octavian Nicolae, Editura Universității „Alexandru Ioan Cuza”, Iași.

Meyer, M. (2010). Principia Rhetorica. Teoria generală a argumentării, Romanian translation by Aurelia Stoica, introduction by Constantin Sălăvăstru, Editura Universității „Alexandru Ioan Cuza”, Iași.

Munteanu, Șt. \& Țâra, V.D. (1983). Istoria limbii române literare, Editura Didactică și Pedagogică, București.

Murphy, J.J. (2001). Rhetoric in the Middle Ages. A History of the Rhetorical Theory from Saint Augustine to the Renaissance, Arizona Center for Medieval and Renaissance Studies, Tempe, AZ.

Oancea, I. (1988). Istoria stilisticii româneşti, Editura Științifică și Enciclopedică, București.

Panaitescu, P.P. (1965). Inceputurile și biruința scrisului în limba română, Editura Academiei R.P.R., București.

Perelman, L. (1991). The Medieval Art of Letter Writing. Rhetoric as Institutional Expression, in Bazerman, Ch. \& Paradis, J. (eds), Textual Dynamics of the Professions. Historical and Contemporary Studies of Writing in Professional Communities, The University of Wisconsin Press, Madison, p. 97-199, [online].

Philippide, Al. (1888). Introducere în istoria limbei și literaturei romîne, Editura Libăriei Frații Șaraga, Iași.

Poster, C. (2007). A Conversation Halved. Epistolary Theory in Greco-Roman Antiquity, in Poster, C. \& Mitchell, L. C. (eds), Letter-Writing Manuals and Instruction from Antiquity to the Present. Historical and Bibliographic Studies, The University of South Carolina Press, p. 21-51.

Pușcariu, S. (1987). Istoria literaturii române. Epoca veche, edited by Magdalena Vulpe, postface by Dan C. Mihăilescu, Editura Eminescu, București. 
Quintilian (1920). Institutio Oratoria. Books I-III, with an English translation by H.E. Butler, Loeb Classical Library, Harvard University Press, Cambridge, MA - London, England.

Radner, K. (ed.) (2014). State Correspondence in Ancient World. From New Kingdom Egypt to the Roman Empire, Oxford University Press, CrossRef.

Roberts, W. (1843). History of Letter-Writing from the Earliest Period to the Fifth Century, William Pickering, London, [online]. Rockinger, L. (1863). Quellen und Erörterungen zur bayerischen Geschichte, Band IX, Teil 1, Georg Franz, München, [online]. Rosetti, Al. (2002). Histoire de la langue roumaine des origines au XVIIe siècle, édition de Dana-Mihaela Zamfir, Clusium, Cuj-Napoca.

Sciarrino, E. (2007). Roman Oratory before Cicero: the Elder Cato and Gaius Gracchus, in Dominik \& Hall, 2007, p. 54-66.

Silvas, A.M. (2007). Gregory of Nyssa: The Letters. Introduction, Translation and Commentary, Brill, Leiden - Boston, MA, CrossRef.

Soare, L. (2013). Crestomație de limbă română veche și modernă (1521-1881), Editura Universitaria, Craiova.

Ștrempel, G. (1978-1992). Catalogul manuscriselor româneşti, vol. I (1987), vol. II (1983), vol. III (1987), vol. IV (1992), Editura Științifică și Enciclopedică, București.

Thomas, C.G. \& Webb, E.K. (1994). From orality to rhetoric: an intellectual transformation, în Worthington, I. (ed.), Persuasion: Greek Rhetoric in Action, Routledge, London - New York.

Urzescu, V. (1840). Epistolar sau modele de scrisori pentru tot felul de trebuințe, cules din cei mai vestiți autori noi și vechi, franțezi și alți cu formulele politeții moderne..., Tipografia Pitarului Constandin Pencovici, București.

Vlad, C. (2008). « Le texte iceberg » aux frontières de la linguistique, de la pragmatique et de la semiotique, in "Revue Roumaine de Linguistique", vol. LIII, no. 3, p. 341-360.

Witt, R. (1982). Medieval "Ars Dictaminis" and the Beginning of Humanism: a New Construction of the Problem, in "Rennaissance Quarterly”, vol. 35, no. 1 (Spring, 1982), p. 1-35, CrossRef. 